\title{
FACTORS AFFECTING INDONESIAN YOUNG LEARNERS' ENGLISH PROFICIENCY LEVEL
}

\author{
${ }^{a}$ Diah Royani Meisani, ${ }^{\mathbf{b}}$ Fuad Abdul Hamied, ${ }^{\mathrm{c} B a h r u d i n}$ Musthafa, \\ ${ }^{\mathrm{d}}$ Pupung Purnawarman
}

(adiahroyani@student.upi.edu, 'meisani_diah.r@ub.ac.id, bfuadah@upi.edu, cdinmusthafa@upi.edu, dpurnawarman@upi.edu)

${ }^{a, b, c, d}$ Universitas Pendidikan Indonesia, Bandung, Indonesia

Jl. Dr. Setiabudi No.229, Isola, Sukasari, Bandung, West Java 40154, Indonesia

${ }^{a}$ Universitas Brawijaya, Malang, Indonesia

Jl. Veteran, Ketawanggede, Lowokwaru, Malang, East Java 65145, Indonesia

\begin{abstract}
This study was aimed at investigating the influencing factors on students' English proficiency levels based on Cambridge English Tests for Children and Young Learners. A preliminary survey was undertaken to select the sample of elementary schools that offered English as a subject. As many as 157 students who sat in Grades 4, 5, and 6 from nine elementary schools participated in this study. The findings revealed that the average of students' scores was at Starters/Movers Level, which is equal to A1 in the Common European Framework of Reference (CEFR). Through multiple regression analysis, three out of five investigated factors were detected to be significantly related to students' English proficiency levels, namely gender, grade level, and school accreditation rank. While rich literature has found gender and grade level as one of the affective variables in language learning, none has studied whether school accreditation status influences young learners' English achievement. It is recommended that schools and related stakeholders consider these factors to ensure effective English teaching to young learners. It is also suggested that future researchers conduct further study on how and under what conditions the factors can contribute to students' English achievement.
\end{abstract}

Keywords: English proficiency level, young learners, Cambridge English tests, influencing factors, elementary school

DOI: http://dx.doi.org/10.15639/teflinjournal.v31i2/204-229 
In English Language Teaching (ELT), evaluation and assessment are among the most frequently investigated areas besides curriculum development, teaching materials, and motivation (Garton \& Copland, 2019; Meidasari, 2017). The complexity of assessment arises when it is placed in the context of assessing young learners' foreign language due to the learners' differences, languages, and knowledge that interact with specific contextual factors and variables (Nikolov, 2016). Hughes (2003) and McKay (2006) similarly point out that assessing young learners is one of the most compound and sensitive issues as it is one of the vital variables interacting in the process of early foreign language learning and teaching.

According to Hughes (2003), the selection of assessment techniques should relate to learners' age group. As some resources define young learners in a varied range of ages, it is pivotal to review the definition of young learners based on their age for the purpose of the study. Young learners who commonly refer to children learning a foreign or second language (McKay, 2006) are defined as 5 to 12 year old children (Cameron, 2001; Hughes, 2003; McKay, 2006), school students up to around 13 years old (Hasselgreen, 2005), 5 to 17 years old (Caudwell, n.d.), 3 to 13 years old (Pinter, 2011), and 5 to 11 years old (Scott \& Ytreberg, 1990). In this study, young learners are framed as elementary school students aged 7 to 12 since the setting of the study is in Indonesia, where children commonly start formal school-based education at the age of 7 and finish the primary level at age 12 .

As an integral part of the language learning process, assessing students is aimed at identifying students' strengths and weaknesses, and helping teachers decide what to teach next and what to revise (Nikolov, 2016). Hence, conducting valid and reliable assessments becomes a critical point as the output influences and determines instruction, classification, and promotion of students' academic progress (Abedi, 2008; ETS, 2016). Different from assessing adults, administering assessments to young learners seems to be more challenging and requires special features. Children's attention span, cognitive abilities, language proficiency, and backgrounds (Hasselgreen, 2005; Hughes, 2003; Musthafa, 2010; Oxford University Press, 2013) should be considered to design a test which is enjoyable, engaging and easy to administer, and can provide accurate results for teachers.

In short, teachers and other test administrators should give thoughtful attention to fundamental characteristics of children so that appropriate test 
techniques can be chosen for valid and reliable testing, as well as positive washback effects. The risks of giving a test that is cognitively beyond young learners' ability and contains tasks that fail to engage them should be avoided as it may not be suitable in terms of motivating and stimulating young learners. A test given to young learners needs to fulfill these four practical conditions: 1) brief and varied as a child's attention span is relatively short; 2) richly illustrated in full color, designed as play-based and containing stories to maintain children's interest and motivation in the test; 3) presented in familiar contexts with clear and straightforward instruction considering children's first language development and cognitive abilities; and 4) targeting language use which children have experienced through social interaction (Hughes, 2003; McKay, 2006; Musthafa, 2010).

Previous studies that examined young learners' English achievement focused on its relationship with gender and age. A lot of studies revealed a relationship between gender and students' English achievement where female students surpassed the performance of male students due to greater motivation and learning style (Becirovic, 2017; Bozinovic \& Sindik, 2011; Glowka, 2014; Lasekan, 2018; Salahshour et al., 2013; Samiyan, 2015; Wang, 2015; Woolfolk, 2014; Zoghi et al. 2013). A number of studies also suggest that age factor affects both the motivation and the ability to acquire a second language (Becirovic \& Huric-Becirovic, 2017; Montrul \& Foote, 2014; Singleton, 1999; Tseng, 2014). While extrinsic motivation decreases with age, intrinsic motivation rises with age. To this respect, teachers should consider students' age in planning, preparing, and implementing English language instructions, so that appropriate stimulation can be given in order to motivate the students in English learning that manifests itself in achievement.

While studies on young learners' English achievement seem to concern mainly the gender and age factors, other variables which potentially affect young learners' English proficiency levels, such as school-related factors, were not adequately explored. School accreditation as a school-related factor is one of the standards for quality in education based on the Indonesian Government Regulation Number 20 the Year 2003 (Schaik, 2009; Sukardjo \& Komarudin, 2009). It was included as one of the investigated variables in the present study as English teaching in primary schools in Indonesia employed bottom-up policy in its implementation (Alwasilah, 2013). With such policy, a school is given the authority to conduct the English teaching practices based on its 
readiness in terms of assigning who teaches the subject, preparing the teaching guidelines, and conducting the assessment. To this respect, school accreditation might indicate the quality of a school, which determines the output of the teaching and learning, including English instructions held by the school. Hence, the current study was intended to fill the gaps in the literature by examining how factors, such as school's accreditation, the frequency of English lessons and student demographics, contribute to young learners' English achievement as measured by an English test for young learners.

Cambridge English Test for Children and Young Learners was chosen as the instrument used in the study due to its validity, reliability, fairness, practicality, and impact (Bailey, 2005). The test is constructed through an extensive program of research and evaluation. Question papers are produced and pretested using strict processes to ensure accuracy and fairness. In addition, the marking and grading are monitored incessantly for consistency. As the exams are based on practical tasks and situations, experiencing the test provides the students with real-life language practice. This activity-based test aims to give positive learning experiences and constructive influence on teaching to all test takers regardless of their national, ethnic and linguistic background, gender, or disability (Cambridge Assessment English, 2019).

From the pedagogical point of view, it is essential to find out the factors that influence young learners' English proficiency levels in order to improve teaching and learning strategies as well as the curriculum implemented. Learning a language has its idiosyncrasies as the abilities of each learner to learn a language are significantly determined by specific aspects. This has directed the current research to examine what factors influence students' English proficiency levels. Based on the aim, the research questions are as follows:

1. What is the overall level of the students' English proficiency based on Cambridge English Tests for Children and Young Learners?

2. What are the relationships between students' English proficiency levels and their age, gender, grade level, school accreditation rank and the frequency of English lessons they have at schools?

Thus, the statistical hypothesis testing is employed with a null hypothesis $\left(\mathrm{H}_{0}\right)$ of no relationship between students' English achievement and their age, gender, grade level, school accreditation rank, and the frequency of English lessons they receive at school. Under the null hypothesis, the test statistic value 
208 TEFLIN Journal, Volume 31, Number 2, July 2020

is expected to be small so that the null hypothesis can be rejected (Creswell, 2012, 2014; Hamied, 2017).

\section{LITERATURE REVIEW}

Previous studies have confirmed that many factors may affect the attainment of learning a language, be they internal or external factors. Learner's age, gender, interest, and motivation in learning the language, and the affective and cognitive style, are included as the internal factors that come from nature or genes (Becirovic, 2017; Major, 2014; McKay, 2006; Meisani, 2017; Scott \& Ytreberg, 1990). On the other hand, the learner's socioeconomic, cultural and home background, the environment, and the atmosphere where language learning occurs are the external factors that contribute to children's experience and knowledge in learning a language. The stakeholders, i.e., policymakers, curriculum developers, school principals, and teachers, need to consider those factors for language teaching and learning to be effectively implemented.

In the Indonesian context, English as a local-content subject at the elementary school was commonly given to the higher graders-Grades 4, 5, and 6. The positive responses of the society towards English lessons at school have then led to the expansion of its implementation to the lower grades as well. However, challenges occur, such as, the absence of national guidelines, and the lack of qualified English teachers and other supplementary requirements of teaching English to young learners (TEYL) (Alwasilah, 2013; Meisani, 2017). The Indonesian Government thus recommends that schools start introducing English to students in higher grades-Grades 4, 5, and 6 whose ages are normally between $10-12$ years old. This is in line with what McKay (2006) states that assessing young learners can be effectively done when their cognitive stage has developed as it is commensurate with the cognitive demand of tasks. Similarly, according to Becirovic and HuricBecirovic (2017), teaching a foreign language to learners above nine years of age is suggested as in this phase, each part of the brain plays its function individually-language functions become grounded within the dominant hemisphere so that the lateralization process is accomplished. It then equips a learner to have the capability to grow vocabulary and world knowledge and to understand and explain more complicated thoughts. Scott and Ytreberg (1990) 
also indicate that by the age of ten children can understand abstracts and symbols represented by words, and communicate systematically as their mother tongue vocabulary has typically developed, and this indirectly encourages the development of their cognition (Becirovic \& Huric-Becirovic, 2017; Birdsong, 2006; Sinanovic \& Becirovic, 2016; Singleton, 1999)

In addition to the age factor, gender is another internal factor that has been widely investigated in terms of its relationship with students' academic interests, needs, and achievements. From the biological viewpoint, females and males are dissimilar in the development of the brain that later affects their cognitive ability and learning style. In terms of the pattern of lateralization, males are more left-hemisphere dominant than females (Yang et al., 2018; Zhogi et al., 2013) which leads them to perform better in the field of science, technology, engineering, and mathematics (STEM) (Solanki \& Xu, 2018). On the other hand, females display superiority in second/foreign language learning. It is the females' sensitivity that helps them perform better in grasping a passage or speech full of different emotions such as happiness or melancholy than males (Becirovic, 2017; Glenberg et al., 2009; Saidi \& Al-Mahrooqi, 2012). Gender research has also lent support to the belief that female supremacy in first language learning has impressively affected hypotheses concerning female superiority in second language learning; the social, cultural and situational contexts in which second languages are acquired cannot be neglected though as both females' and males' behaviors and attitudes are shaped by the family and overall culture they grew up and socialized with (Eagly \& Karau, 2002; Zhogi et al., 2013).

Besides the abovementioned factors, school is recognized as one of the crucial factors to support students' second/foreign language learning process. In Indonesian context, one of the reasons is because the school may be the only place where students learn English as it is a foreign language in Indonesia. As Indonesian parents do not commonly speak English at home (Meisani, 2018) and exposure to the English language is not richly provided outside the English classroom (Musthafa \& Hamied, 2014), school plays an essential role in promoting English learning to its students (Musthafa, 2010).

Concerning the school quality, efforts have been undertaken by the Government to improve services in education both at the central level-by comprehensively constructing educational policies, and at the regional levelby implementing the School Accreditation Program (SAP) (Haryati, 2014; 
Schaik, 2009). For Elementary and Junior High School, the accreditation is handled at the municipality level, while for Senior High School, it is done at the provincial level. Furthermore, eight standards are set by the National Accreditation Board for schools to fulfill in order to be accredited. Based on the Ministerial Regulation Number 082/BAN-SM/SK/2018 about School and Madrasah Accreditation, the standards include Standards of Contents, Standards of Process, Standards of Graduate Competence, Standards of Teachers and Education Administrators, Standards of Infrastructure, Standards of Management, Standards of Finance, and Standards of Evaluation (Haryati, 2014; Malik et al., 2018). The accredited school is then given a rank A (the highest), B, or C, based on the assessment results (Schaik, 2009).

Through the evaluation and assessment of those eight standards, accreditation plays a vital part in school development by encouraging schools to do comprehensive reflection, giving opportunity and guidance for schools to play the role as a professional learning community, and exposing detailed description about schools' improvement efforts around specific, targeted, measurable objectives (Canul, 2009; CHEA, 2010; Enomoto \& Conley, 2015; Haryati, 2014; Karyanto et al., 2015). Review from the external parties, in this case, the representative of the School Accreditation Board, brings beneficial impact on school improvement. It allows schools to reflect on their quality through a different point of view, and provides information on their strengths and weaknesses. In this way, schools can focus on setting clear, directed, assessable improvement goals as the basis to maintain accreditation and ensure continuous improvement (Canul, 2009).

In the context of TEYL in Indonesia which follows the bottom-up policy, school quality should contribute to determining the success of the implementation of English education since it is the school itself that initiates the implementation of the English teaching by considering all of its potentials to conduct the program (Alwasilah, 2013). Accreditation indicates the quality of teachers, education administrators, as well as the leadership of the principal (Haryati, 2014). Therefore, it is supposed that the higher the rank of the accreditation, the better the quality of the human resources and facilities, and the implementation of the school program, including the English teaching and learning activities. 


\section{METHOD}

By employing quantitative research based on the data gathered through questionnaires and the English test, the study investigated the factors that influenced students' English proficiency. In this study, the students' English test score was the dependent variable and the students' age, gender, grade level, the school accreditation rank, and the frequency of English lessons the students had at school, were the categorical independent variables (Creswell, 2012, 2014; Hamied, 2017).

\section{Participants}

This study was conducted in a selected municipality in East Java, Indonesia, whose area was segmented into five sub-districts. There were 274 elementary schools under the Regional Office of Education in the city. Nine schools were selected to represent the population based on the criteria which were elaborated in the following section. Ethics approval was granted by the Regional Office of Education, and consent was attained from all of the participants before the data collection began.

\section{The Schools}

Nine participating schools were recruited based on five criteria as follows: 1) English curriculum; 2) accreditation; 3) National Examination results from 2014 to 2017; 4) location; and 5) agreement of participation. The first point required the participating schools to have English subject in their curriculum as the basic criteria. This is to conform with fairness and justice values in conducting a test, particularly the equity factor in which the test takers are in the state of receiving credit or an equal share of appropriate claims (Kunan, 2012). As many as 168 out of 184 schools which returned the questionnaire confirmed that they conducted TEYL. Next, the schools were classified and ranked based on their accreditation and the results of the National Examination in the last four academic years. The selection also concerned the schools' location so that the participating schools could represent five sub-districts in this city. Finally, nine participating schools were chosen after they confirmed their agreement to take part in the study and thus to permit their students to participate in the English tests. 


\section{The Students}

Eligible participants in this study were higher graders who sat in Grades 4, 5 , and 6 of the nine selected schools and who agreed to participate in the study. As elaborated in the previous section, children above nine years old, who are at higher grade levels, have developed their cognitive ability so that assessment can be effectively done (Caudwell, n.d.; McKay, 2006). A total of 157 students aged $8-16$ years old agreed to participate by taking the Cambridge English tests for Children and Young Learners. Although it was clearly defined previously that the age of young learners was between $7-12$, five of the participating students were at the age of 13 ( 2 students), 14 (1 student), and 16 (1 student). It occurred because one of the schools with accreditation rank C still accepted students with interrupted schooling who were commonly older than the regular students. Nevertheless, this case was not taken into account in this study as it did not influence the results. In terms of parents' agreement, the participating schools helped the researchers to inform the parents about the activities in which their children were taking part to obtain their approval.

\section{Instruments}

The data in the study were collected through questionnaires and tests, which are elaborated as follows.

\section{Questionnaire}

A preliminary survey was conducted in order to select the sample of the study. A questionnaire, modified from the previous research (Bailey, 2006; Mardiani, 2011), was employed to capture the data needed regarding the elementary schools in the city where the study was conducted and to select those that fulfilled the five criteria mentioned earlier. The questionnaire had been validated by two experts in English Education and English for Young Learners (EYL). Comments and suggestions from the reviewers were used to reconstruct and revise the unclear and ambiguous questions and rephrase the complex items. Ineffective and nonfunctioning questions were discarded altogether. Then, in order to gain the empirical data of schools conducting English teaching, questions were made to explore the school accreditation and location, and English curriculum. In the last section, the principals were asked whether they agreed to participate in further study or not. 


\section{Young Learners' English Test}

The test administered in this study was taken from the Online Cambridge English Test for Children and Young Learners. This was an open-access test that could be retrieved through the link http://www.cambridgeenglish.org/testyour-english/young-learners/. It was originally a web-based test which required online administration, but the researcher modified it to be paper-based without changing the contents in consideration of the schools which do not have adequate internet access and lack devices to conduct the online test to many students.

Although the city where the study was conducted was considered the second-largest city in the province, where internet access should have grown rapidly and reached the entire region, some of its areas still had outdated and unreliable technology. Two participating schools were located in rural areas; one of them was in a remote rural area with no internet connection. The number of computers that the schools had was also limited, so it was considered ineffective for the schools to administer the online test. It is true that previous studies suggest computer-based testing as it can create more efficient and precise quality estimation than the traditional paper and pencil testing could do (Chen, 2010; Mizumoto et al. 2017). However, a viable option was taken by having the test on paper as it was easier to administer (McKay, 2006), besides avoiding network congestion during the test and other challenges mentioned above.

The test used in the study was designed for children aged $7-12$ and consisted of 20 multiple-choice questions. It had four parts covering listening in Part 1 and 2, and Reading and Writing in Part 3 and 4. The test was authored and published by the University of Cambridge ESOL Examinations (UCLES). The detailed contents of the test can be seen in Table 1 .

Table 1. The Contents of Cambridge English Test for Children \& Young Learners

\begin{tabular}{|c|c|c|c|c|c|}
\hline Part & Components & $\begin{array}{l}\text { Main skill } \\
\text { focus }\end{array}$ & Input & $\begin{array}{l}\text { Expected } \\
\text { response }\end{array}$ & $\begin{array}{c}\text { No. of } \\
\text { questions }\end{array}$ \\
\hline 1 & Listening & $\begin{array}{l}\text { Listening for } \\
\text { particular } \\
\text { information } \\
\text { about various } \\
\text { kinds, e.g., }\end{array}$ & $\begin{array}{l}\text { 3-option } \\
\text { multiple- } \\
\text { choice } \\
\text { pictures and } \\
\text { dialogues }\end{array}$ & $\begin{array}{l}\text { Circle the letter } \\
\text { next to correct } \\
\text { picture }\end{array}$ & 5 \\
\hline
\end{tabular}


214 TEFLIN Journal, Volume 31, Number 2, July 2020

\begin{tabular}{|c|c|c|c|c|c|}
\hline Part & Components & $\begin{array}{l}\text { Main skill } \\
\text { focus }\end{array}$ & Input & $\begin{array}{l}\text { Expected } \\
\text { response }\end{array}$ & $\begin{array}{c}\text { No. of } \\
\text { questions }\end{array}$ \\
\hline & & $\begin{array}{l}\text { numbers, } \\
\text { describing } \\
\text { people etc. }\end{array}$ & & & \\
\hline 2 & Listening & $\begin{array}{l}\text { Listening for } \\
\text { specific } \\
\text { information on } \\
\text { specific days }\end{array}$ & $\begin{array}{l}\text { Picture and } \\
\text { name of days }\end{array}$ & $\begin{array}{l}\text { Write the } \\
\text { number of the } \\
\text { correct picture } \\
\text { next to the } \\
\text { matching day }\end{array}$ & 5 \\
\hline 3 & $\begin{array}{l}\text { Reading and } \\
\text { Writing }\end{array}$ & $\begin{array}{l}\text { Reading a text } \\
\text { and completing } \\
\text { missing words }\end{array}$ & $\begin{array}{l}\text { Cloze text } \\
\text { and 3-option } \\
\text { multiple- } \\
\text { choice words }\end{array}$ & $\begin{array}{l}\text { Choose and } \\
\text { circle the } \\
\text { missing words } \\
\text { correctly }\end{array}$ & 5 \\
\hline 4 & $\begin{array}{l}\text { Reading and } \\
\text { Writing }\end{array}$ & $\begin{array}{l}\text { Reading a } \\
\text { dialogue and } \\
\text { choosing the } \\
\text { correct } \\
\text { responses }\end{array}$ & $\begin{array}{l}\text { Short } \\
\text { dialogue with } \\
\text { multiple- } \\
\text { choice } \\
\text { responses }\end{array}$ & $\begin{array}{l}\text { Choose the } \\
\text { correct response } \\
\text { by writing the } \\
\text { alphabet of the } \\
\text { correct response }\end{array}$ & 5 \\
\hline
\end{tabular}

This test spans three ability levels: Starters, Movers, and Flyers. Starters are at a level equivalent to pre-A1 of Common European Framework of Reference for Languages (CEFR), Movers are at A1, and Flyers are equivalent to A2. Table 2 displays the qualification levels based on the test takers' range scores. It shows that 0 (zero) is the lowest score and 20 is the highest.

Table 2. Cambridge English Qualification Levels

\begin{tabular}{cc}
\hline Range Scores & English Qualification Levels \\
\hline $0-7$ & Starters \\
\hline $8-10$ & Starters/Movers \\
\hline $11-14$ & Movers \\
\hline $15-17$ & Movers/Flyers \\
\hline $18-20$ & Flyers \\
\hline
\end{tabular}

\section{Data Analysis}

In this study, as data were collected through two techniques, questionnaire and test, analysis for both data were conducted separately. Data gathered from the questionnaires were first inputted in Google Form - a free web-based 
application that is used to create forms for data collection purposes. As it provides a response sheet that loads and displays data in diagrams and graphics, trends can be easily seen (Cyber Acoustics, 2017). The results of the test were analyzed using Statistical Package for the Social Sciences (SPSS), version 25.0, which provides many different types of analyses, data transformations, and forms of output (Arkkelin, 2014; Larson-Hall, 2010). Multiple regression approach was chosen to analyze the data as there were more than two independent variables investigated.

Hence, to see whether there was any relationship between the dependent and the independent variables, the p-value of each independent variable was examined. This was also employed to find out whether the null hypothesis $\left(\mathrm{H}_{0}\right)$ was rejected or accepted. P-value is defined as the probability of observing the given value of the test statistic, or greater, under the null hypothesis. To reject the null hypothesis, the cutoff value of 0.05 was set - when the p-value was under 0.05 , the null hypothesis was rejected, and a statistically significant difference between groups existed (Creswell, 2012, 2014; Hamied, 2017). Furthermore, the coefficient of regression $(\beta)$ was also observed to determine the most dominating independent variable that had a relationship with the dependent variable.

\section{FINDINGS AND DISCUSSION}

\section{Findings}

The findings of the present study include the results of the English test for young learners and the results of multiple regression and ANOVA analyses to figure out the contributing factors to students' English proficiency levels. The questionnaire results provided data on each school accreditation rank and the frequency of English lessons per week, which were used in the selection of the participants as well as the statistical analyses. The exam papers provided data on students' age, grade level, and gender.

\section{Results of the English Test}

A total of 157 elementary school students were included in this study. The number of male and female students were slightly different in number, where the number of female was 15 more than the male group. The age ranged from 8 to 16 years old. It was explained formerly that five students were above twelve 
years old. However, this does not affect the results of the study. Table 3 presents detailed information about the student and school participants.

Table 3. Demographic Characteristics of the Participating Students and Schools

\begin{tabular}{|c|c|c|c|}
\hline Category & Characteristics & $\mathbf{N}$ & $\%$ \\
\hline \multirow{7}{*}{$\begin{array}{c}\text { Student } \\
(\mathrm{n}=157)\end{array}$} & Gender & & \\
\hline & - Male & 86 & 54.78 \\
\hline & - Female & 71 & 45.22 \\
\hline & Grade \& Age & & \\
\hline & - Four $(8-11$ years old $)$ & 58 & 36.95 \\
\hline & - Five ( $8-12$ years old $)$ & 48 & 30.57 \\
\hline & - Six $(10-16$ years old $)$ & 51 & 32.48 \\
\hline \multirow{7}{*}{$\begin{array}{l}\text { School } \\
(\mathrm{n}=9)\end{array}$} & Type & & \\
\hline & - Public & 4 & 44.44 \\
\hline & - Private & 5 & 55.56 \\
\hline & Accreditation Rank & & \\
\hline & - A & 3 & 33.33 \\
\hline & - $\mathrm{B}$ & 3 & 33.33 \\
\hline & - $\mathrm{C}$ & 3 & 33.33 \\
\hline
\end{tabular}

Next, the results of the Cambridge English Test for Children and Young Learners were classified based on the Cambridge Qualification Level that can be seen in Table 2. As the test spanned three ability levels-Starters, Movers, and Flyers, two other levels might appear among those three when students' scores were $8-10$ (Starters/Movers) or 15-17 (Movers/Flyers) out of 20. Based on the notes on the website of Cambridge Assessment English, when a student was in this condition, the teacher could give a recommendation based on student's English achievement at school to decide his/her Cambridge Qualification Level. As teachers of English at the participating schools had been informed about this, they were willing to collaborate with the researchers to give the recommendation to place their students at the appropriate level of Cambridge qualification based on the students' English achievement in their English class at school. The results of students' English test are presented in Table 4. 
Meisani et al., Factors Affecting Young Learners' Proficiency Level 217

Table 4. The Results of the Students' English Test

\begin{tabular}{ccc}
\hline Range Scores & Cambridge Qualification Levels & Number of Students \\
\hline $0-7$ & Starters & 65 \\
\hline $8-10$ & Starters/Movers & 35 \\
\hline $11-14$ & Movers & 29 \\
\hline $15-17$ & Movers/Flyers & 15 \\
\hline $18-20$ & Flyers & 13 \\
\hline & Total & $\mathbf{1 5 7}$ \\
\hline
\end{tabular}

Table 4 shows that 35 students were at the Starters/Movers level and 15 others were at the Movers/Flyers. Based on their teachers' reference, 21 out of 35 students who gained $8-10$ were included at the Movers level, and 14 others were at the Starters. Moreover, 9 out of 15 students whose score ranged $15-17$ were included in the Flyers group, while six others were at the Movers level. Thus, after mapping the total students into three categories, there were 22 students at the Flyers level, 56 students at the Movers level, and 79 students at the Starters level. The percentage of each level is displayed in Figure 1.

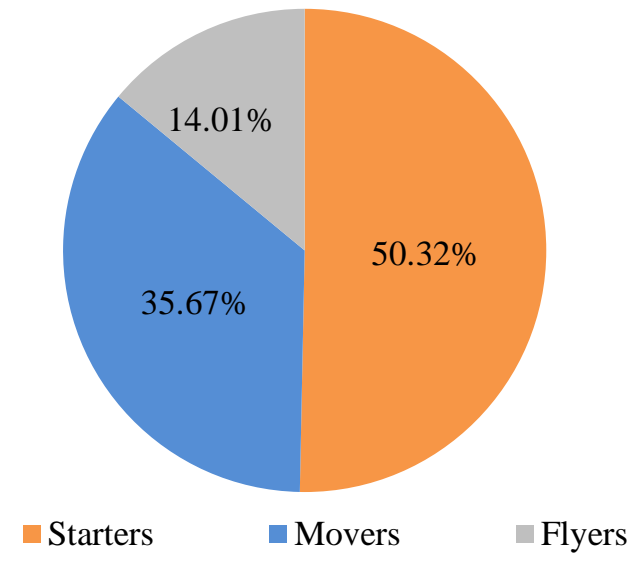

Figure 1. Students' Cambridge Qualifications

Based on the data presented in Figure 1, the English proficiency levels of elementary school students in this city were dominated by the students who were at the Starters level as they covered half of the total participants. There 
were 79 out of 157 students who reached this level. Then, the percentages typically declined as the qualification level got higher with 56 students at the Movers level and 22 at the Flyers.

Next, to see the overall level of the students' English proficiency based on the Cambridge English Test, the mean score was examined. Table 5 shows the average score of the students overall, as well as how students in each school group differ in the test results. It presents detailed information about the number of students at each Cambridge Qualification Level. The majority of the students were at Starters level. Most of the students at this level studied at the schools with accreditation rank B and $\mathrm{C}$. On the other hand, most of the members of the Flyers group were students from schools with the highest accreditation rank; none came from a school with accreditation rank C. In terms of the overall proficiency level, the average score of 9.61 shows that in general, the students are at the level of Starters/Movers. Further explanations about the competencies and proficiency of students at this level are presented in the discussion section.

Table 5. The Mean Score of the Students' English Test

\begin{tabular}{|c|c|c|c|c|c|c|c|}
\hline \multirow[b]{2}{*}{$\underset{0}{0}$} & \multirow[b]{2}{*}{ 园 } & \multicolumn{4}{|c|}{ Participants } & \multirow[b]{2}{*}{ 量 } & \multirow[b]{2}{*}{ 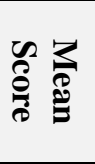 } \\
\hline & & $\begin{array}{c}\text { School } \\
\text { Accreditation } \\
\text { Rank } \\
\end{array}$ & $\begin{array}{c}\Sigma \text { Students } \\
\text { \& Gender }\end{array}$ & $\begin{array}{l}\% \text { of } \\
\text { the } \\
\text { group }\end{array}$ & $\begin{array}{c}\begin{array}{c}\% \text { of the } \\
\text { total } \\
\text { participants }\end{array} \\
\end{array}$ & & \\
\hline \multirow{4}{*}{ Starters } & \multirow{4}{*}{$\begin{array}{c}\text { Pre- } \\
\text { A1 }\end{array}$} & $\mathrm{A}$ & $2(2 \mathrm{~F} ; 0 \mathrm{M})$ & 2.53 & 1.27 & \multirow{4}{*}{453} & \multirow{4}{*}{5.73} \\
\hline & & B & $\begin{array}{l}43(21 \mathrm{~F} ; 22 \\
\mathrm{M})\end{array}$ & 54.43 & 27.39 & & \\
\hline & & $\mathrm{C}$ & $\begin{array}{l}34(19 \mathrm{~F} ; 17 \\
\mathrm{M})\end{array}$ & 43.04 & 21.66 & & \\
\hline & & Total & 79 & 100 & 50.32 & & \\
\hline \multirow{4}{*}{ Movers } & \multirow{4}{*}{ A1 } & A & $\begin{array}{l}33(18 \mathrm{~F} ; 15 \\
\mathrm{M})\end{array}$ & 58.93 & 21.02 & \multirow{4}{*}{655} & \multirow{4}{*}{11.70} \\
\hline & & B & $\begin{array}{l}12(6 \mathrm{~F} ; 6 \\
\mathrm{M})\end{array}$ & 21.43 & 7.64 & & \\
\hline & & $\mathrm{C}$ & $\begin{array}{l}11(6 \mathrm{~F} ; 5 \\
\mathrm{M})\end{array}$ & 19.64 & 7.01 & & \\
\hline & & Total & 56 & 100 & 35.64 & & \\
\hline \multirow[t]{2}{*}{ Flyers } & \multirow[t]{2}{*}{ A2 } & A & $\begin{array}{l}20(16 \mathrm{~F} ; 4 \\
\mathrm{M})\end{array}$ & 90.91 & 12.74 & \multirow[t]{2}{*}{500} & \multirow[t]{2}{*}{18.18} \\
\hline & & $\mathrm{B}$ & $2(2 \mathrm{~F} ; 0 \mathrm{M})$ & 9.01 & 1.27 & & \\
\hline
\end{tabular}


Meisani et al., Factors Affecting Young Learners' Proficiency Level 219

\begin{tabular}{|c|c|c|c|c|c|c|c|}
\hline \multirow{4}{*}{ 象 } & \multirow{4}{*}{ 图 } & \multicolumn{4}{|c|}{ Participants } & \multirow{4}{*}{ 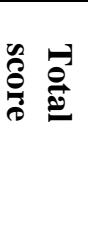 } & \multirow{4}{*}{$\begin{array}{ll}n & 2 \\
0 & 0 \\
0 & 0\end{array}$} \\
\hline & & $\begin{array}{c}\text { School } \\
\text { Accreditation } \\
\text { Rank }\end{array}$ & $\begin{array}{l}\Sigma \text { Students } \\
\text { \& Gender }\end{array}$ & $\begin{array}{l}\% \text { of } \\
\text { the } \\
\text { group }\end{array}$ & $\begin{array}{c}\% \text { of the } \\
\text { total } \\
\text { participants }\end{array}$ & & \\
\hline & & $\mathrm{C}$ & 0 & 0 & 0 & & \\
\hline & & Total & 22 & 100 & $14 . .01$ & & \\
\hline $\begin{array}{l}\text { Total } \\
\text { Mean }\end{array}$ & & & $\begin{array}{l}157 \\
(86 \mathrm{~F} ; 71 \mathrm{M})\end{array}$ & & & $\begin{array}{r}1508 \\
9.61\end{array}$ & \\
\hline
\end{tabular}

\section{The Relationship between the Test Scores and Other Variables}

Further investigation was conducted to discern the factors that influenced students' English proficiency. In this study, factors, namely: students' age, grade level, gender, school accreditation rank, and the frequency of English lessons per week, were examined to answer the second research question. Data from the questionnaire filled out by the school principal provided information about each school accreditation rank and the frequency of English lessons per week. The rest of the variables, that is, students' age, grade level, and gender, were obtained from the exam papers. The summary of the values of Mode, Standard Deviation, and Range of the variables investigated in this study is presented in Table 6.

Table 6. The Mode, Standard Deviation, and Range of the Investigated Variables $(\mathbf{n}=\mathbf{1 5 7})$

\begin{tabular}{clccc}
\hline No & Variable & Mo & SD & Range \\
\hline 1 & Age & 10 & 1.19 & $8(8-16)$ \\
\hline 2 & Grade level & 4 & .83 & $2(4-6)$ \\
\hline 3 & Gender & Female & .50 & $1(1-2)$ \\
\hline 4 & School Accreditation Rank & B & .80 & $2(1-3)$ \\
\hline 5 & Frequency of English lessons & Once a week & .31 & $1(1-2)$ \\
\hline 6 & Test score & 6 & .78 & $19(1-20)$ \\
\hline
\end{tabular}

As shown in Table 6, most of the participants were at the age of 10. In terms of grade level and gender, the participants were dominated by fourth graders and female students. Furthermore, there were more students that studied at the schools with accreditation rank B compared to the ones who studied at the other two groups of accreditation rank. Most of the participating schools scheduled the English subject once a week for two periods of a lesson, 
or $2 \times 35$ minutes. Also, the mode of the only dependent variable, test scores, showed that score 6 was the most frequently occurring.

In the analysis, dummy variables as the indicator variables were employed to represent the categorical variables, so interpretation of results could be easily made. Three points were involved in underpinning the selection of dummy variables, including: 1) the normative category; 2) the largest category; and 3) the category with the lowest, the highest or the middle mean (Laerd Statistics, 2018). Thus, among all of the categories of the variables, the following categories were chosen as the predictors: female, Grade 5, Grade 4, Accreditation Rank A, Accreditation Rank B, the frequency of English lessons, and age. Then, the Model Summary and the Analysis of Variance (ANOVA) in Tables 7 and 8 display how these variables contributed to the test score.

Table 7. Model Summary

\begin{tabular}{cccc}
\hline $\mathbf{R}$ & $\mathbf{R}$ Square & Adjusted R Square & Std. Error of Estimate \\
\hline .800 & .640 & .615 & 2.96753 \\
\hline
\end{tabular}

Table 8. ANOVA

\begin{tabular}{llcrcc}
\hline Model & Sum of Squares & Df & Mean Square & F & P-value \\
\hline Regression & 2281.803 & 10 & 228.180 & 25.911 & .000 \\
\hline Residual & 1285.713 & 146 & 8.806 & & \\
\hline Total & 3567.516 & 156 & & & \\
\hline
\end{tabular}

The information from Table 7 confirms that the contribution of gender, age, grade, accreditation rank, and the frequency of the lesson to the test scores is $80.0 \%$ ( $\mathrm{R}$ square $=0.8$ ). The rest was explained by other aspects besides those variables. Furthermore, to determine whether the test was statistically significant, the value of $F$ was also seen through ANOVA. As mentioned before, the cutoff of the p-value is $5 \%$ as shown in Table 8 . With the value of $\mathrm{F}=25.911$ and $\mathrm{p}<0.05$, it can be concluded that all of the independent variables were significantly related to the students' test scores. Thus, the null hypothesis was rejected.

To see how the variables influenced the students' test scores individually, the coefficient of regression $(\beta)$ and the p-value of every independent variable were examined. The data are presented in Table 9. 
Meisani et al., Factors Affecting Young Learners' Proficiency Level 221

Table 9. The Regression Coefficients and the P-Values of the Independent Variables

\begin{tabular}{|c|c|c|c|c|c|}
\hline \multirow{2}{*}{ Model } & \multicolumn{2}{|c|}{$\begin{array}{l}\text { Unstandardized } \\
\text { Coefficients }\end{array}$} & \multirow{2}{*}{$\begin{array}{c}\text { Standardized } \\
\text { Coefficients }\end{array}$} & \multirow{2}{*}{$\mathbf{T}$} & \multirow{2}{*}{ P-value } \\
\hline & Beta & $\begin{array}{c}\text { Standard } \\
\text { Error }\end{array}$ & & & \\
\hline (Constant) & 11.771 & 4.762 & & 2.472 & .015 \\
\hline Female & 1.875 & .504 & .196 & 3.719 & .000 \\
\hline Grade 4 & -1.459 & 1.295 & -.148 & -1.126 & .262 \\
\hline Grade 5 & -1.787 & .875 & -.173 & -2.043 & .043 \\
\hline Accreditation A & 4.351 & 1.230 & .435 & 3.537 & .001 \\
\hline Accreditation B & -1.515 & 1.358 & -.153 & -1.116 & .266 \\
\hline Age & -.185 & .344 & -.046 & -.538 & .591 \\
\hline Frequency & 1.630 & 1.449 & .106 & 1.125 & .262 \\
\hline
\end{tabular}

Among the investigated variables listed in the table, the p-values of the three variables are under 5\%, which means they are related to the dependent variable. The three variables include gender, grade level, and school accreditation rank. Other variables, that is, age and frequency of English lessons, do not show any relationship with students' English achievement. In order to see which of the factors is the most dominant, their coefficients of regressions were compared. As the coefficient of regression of school accreditation rank shows the highest value, it can be concluded that this variable is the most dominant of all.

\section{Discussion}

Based on the salient characteristics of the CEFR level, Starters/Movers is equal to level A1-the lowest level of generative language use. In terms of interactive and productive skills, students at this level are able to interact in a simple way by asking as well as answering simple questions about themselves, where they live, people they know, and things they possess. Also, they can initiate and respond to simple statements in areas of abrupt need or on very familiar topics, rather than relying only on a very limited rehearsed, lexically organized repertoire of situation-specific phrases. Besides, their receptive skills are commonly very slow, carefully enunciated, with long pauses to allow assimilation of meaning. They can identify familiar names and understand very 
short simple texts with visual support usually by re-reading or getting repetition when needed (Language Policy Division, 2009).

In terms of the investigation on the relationship between the affecting variables and students' English achievement, the statistical analysis in Table 8 confirms that the variables of age and frequency of English lessons are not related to students' English achievement. Although several previous studies have proved that age relates significantly to second language acquisition (Becirovic, 2017; Montrul \& Foote, 2014; Tseng, 2014), this variable appears not to influence the students' English test scores in this study. In other words, this discovery rejects the previous findings.

A similar case occurs in the frequency of English lessons. This variable does not show any relationship with the test scores, either. This finding contradicts the theory of Spolsky (1989) about the condition of exposure which states that the more time spent learning any aspect of language, the more will be learned. It is also different from the finding in the study by Moinzadeh et al. (2008) which suggests two sessions per week for significant development of English skills.

Next, gender has been abundantly investigated and proved to have a substantial influence on learners' English learning. Plenty of previous studies have demonstrated that gender has a major effect on English language learning. As hypothesized, gender comes to be one of the supporting factors in the study, which corroborates the earlier findings. This also applies to grade level, which is linear with the previous discoveries (Meisani, 2017). It supports the notion that as grade level increases, students' linguistic ability develops, so they have more capability to understand and produce more sophisticated words and more complex structures.

Where this paper goes further than the previous studies is the exploration of the role of school accreditation status in students' English achievement. As shown by the p-value and the coefficient of regression, the school accreditation rank becomes the most dominant factor that influences students' English scores. The accreditation system is one of the ways through which the Indonesian Government distinguishes a school quality (Schaik, 2009). A school with the highest accreditation rank, that is, rank $\mathrm{A}$, is the one that has both competent teachers and education administrators. The principal and the vice principals are also the ones with high-quality leadership who play a significant 
role in managing the school so that the best accreditation rank can successfully be achieved (Haryati, 2014).

Furthermore, included as one of the standards to evaluate school accreditation is teacher quality. High proficiency of teachers may positively impact their confidence, teaching skills and content, students' motivation, and learning effectiveness (Butler, 2004; Elder \& Kim, 2014; Hanushek \& Rivkin, 2012; Nakata, 2010; Othman \& Kiely, 2016; Tsang, 2017). Schools should be concerned with teachers' educational backgrounds in recruitment as it affects their pedagogical practices (Westbrook et al., 2013). Thus, related to school's roles in ELT practices, the results of this study suggest three major points that a school should pay attention to if effective TEYL is to be conducted: 1) English teacher recruitment, 2) EYL teaching practices, and 3) EYL teaching facilities and resources.

\section{CONCLUSIONS}

The results from this study indicate that the participants have reached Starters/Movers level of Cambridge Assessment English, which is equal to A1 of CEFR. The results reject the null hypothesis, which formerly states that there was no relationship between students' English proficiency and their age, gender, grade level, school accreditation rank, and the frequency of English lessons per week. Although not all of the investigated factors show a correlation, three factors, gender, grade level, and school accreditation rank, turn out to be significantly related to the students' English test scores. Accreditation rank appears to be the most dominant factor which implies the crucial needs of good quality of school management in teacher recruitment, teaching practices, and facility provision.

\section{Funding}

This research was fully funded by LPDP (Indonesia Endowment Fund for Education), Ministry of Finance, Republic of Indonesia. 
224 TEFLIN Journal, Volume 31, Number 2, July 2020

\section{REFERENCES}

Abedi, J. (2008). Measuring students' level of English proficiency: Educational significance and assessment requirements. Educational Assessment, 13(23), 193-214.

Alwasilah, A. C. (2013). Policy on foreign language education in Indonesia. International Journal of Education, 7(1), 1-19.

Arkkelin, D. (2014). Using SPSS to Understand Research and Data Analysis. Retrieved from https://scholar.valpo.edu/cgi/viewcontent.cgi?article=1000 \&context=psych_oer

Bailey, A. L. (2005). Test review. Language Testing, 22(2), 242-252.

Bailey, K. M. (2006). Language teacher supervision. Cambridge University Press.

Becirovic, S. (2017). The relationship between gender, motivation and achievement in learning English as a foreign language. European Journal of Contemporary Education, 6(2), 210-220.

Becirovic, S. \& Huric-Becirovic, G. (2017). The role of age in students' motivation and achievement in learning English as a second language. Journal of Linguistic and Intercultural Education - JoLIE, 10(1), 23-35.

Birdsong, D. (2006). Age and second language acquisition and processing: A selective overview. Language Learning, 56(1), 9-49.

Bozinovic, N. \& Sindik, J. (2011). Gender differences in the use of learning strategies in adult foreign language learners. Metodicki obzori, 6(1), 5-20.

Butler, Y. G. (2004). What level of English proficiency do elementary school teachers need to attain to teach EFL? Case studies from Korea, Taiwan, and Japan. TESOL Quarterly, 38(2), 245-78.

Cambridge Assessment English. (2019). Ensuring quality and fairness. Retrieved from https://www.cambridgeenglish.org/why-choose-us/ ensuring- quality-and-fairness/

Cameron, L. (2001). Teaching languages to young learners. Cambridge University Press.

Canul, Y. C. (2009). A self-study: The impact of accreditation on school improvement. Retrieved from https://www.advanc-ed.org/source/selfstudy-impact-accreditation-school-improvement

Caudwell, G. (n.d.). Assessing young learners. Retrieved from https://www.britishcouncil.org/sites/default/files/transcripts_assessing_yo ung_learners.pdf 
CHEA (Council for Higher Education Accreditation). (2010). Effective practices: The role of accreditation in student achievement. Retrieved from https://www.chea.org/userfiles/CHEA\%20Advisory\%20Statements/ Effective\%20Practice\%20Revised3.pdf

Chen, S. (2010). A procedure for controlling general test overlap in computerized adaptive testing. Applied Psychological Measurement, 34(6), 393-409.

Creswell, J. W. (2012). Educational research: Planning, conducting, and evaluating quantitative and qualitative research. Pearson.

Creswell, J. W. (2014). Research design: Quantitative, qualitative, and mixed methods approach. Sage Publication.

Cyber Acoustics. (2017). Tech tip: The benefits of using Google Forms in education. Retrieved from https://www.cyberacoustics.com/education/ Blog?archives=04-07-2017\&title=Tech-Tip-The-Benefits-of-UsingGoogle-Forms-in-Education $\% 25 \mathrm{C} 2 \% 25 \mathrm{~A} 0 \% 25 \mathrm{C} 2 \% 25 \mathrm{~A} 0$

Eagly, A. H. \& Karau, S. J. (2002). Role congruity theory of prejudice toward female leaders. Psychological Review, 109(3), 573-598.

Elder, C., \& Kim, S. (2014). Assessing teachers' language proficiency. In A. J. Kunnan, (Ed.). The companion to language assessment (pp. 1-17). Wiley.

Enomoto, E. K. \& Conley, S. (2015). School accreditation process as routinized action: Retaining stability while promoting reform. Journal of School Leadership, 25(1), 133-156.

ETS (Educational Testing Service). (2016). ETS guidelines for fair tests and communications. Retrieved from https://www.ets.org/s/about/pdf/ets_ guidelines_for_fair_tests_and_communications.pdf

Garton, S. \& Copland, F. (2019). The Routledge handbook of teaching English to young learners. Routledge.

Glenberg, A. M., Webster, B. J., Mouilso, E., Havas, D., \& Lindeman, L. M. (2009). Gender, emotion, and the embodiment of language comprehension. Emotion Review, 1(2), 151-161.

Glowka, D. (2014). The impact of gender on attainment in learning English as a foreign language. Studies in Second Language Learning and Teaching, 4(4), 617-635.

Hamied, F. A. (2017). Research methods: A guide for first time researchers. UPI Press. 
Hanushek, E. A. \& Rivkin, S. G. (2012). The distribution of teacher quality and implications from policy. Annual Reviews, 4(1), 131-157.

Haryati, S. (2014). An evaluative review of school accreditation implementation program in Indonesian contexts. International Education Studies, 7(5), 138-146.

Hasselgreen, A. (2005). Assessing the language of young learners. Language Testing 2005, 22(3), 337-354.

Hughes, A. (2003). Testing for language teachers. Cambridge University Press.

Karyanto, U. G. \& Rahman, A., Darwin, A. R. (2015). Implikasi akreditasi sekolah terhadap peningkatan mutu tata kelola SMK Negeri 1 Oku [The implications of school accreditation on improving the quality of school governance at SMK Negeri 1 Oku]. Jurnal Manajemen Pendidikan Indonesia, 7(2), 43-57.

Kunan, A. J. (2012). High-stakes language testing. In C. Chapelle (Ed.), The encyclopedia of applied linguistics. Retrieved from https://doi.org/10.1002/9781405198431.wbeal0504

Laerd Statistics. (2018). Creating dummy variables in SPSS Statistics. Retrieved from https://statistics.laerd.com/spss-tutorials/creating-dummyvariables-in-spss-statistics.php

Language Policy Division. (2009). Relating language examinations to the Common European Framework of Reference for languages: Learning, teaching, assessment (CEFR). Retrieved from https://rm.coe.int/ $1680667 \mathrm{a} 2 \mathrm{~d}$

Larson-Hall, J. (2010). A guide to doing statistics in second language research using SPSS. Routledge.

Lasekan, O. (2018). Gender differences in English proficiency among early, middle and late immersion undergraduate students: The role of individual difference factors. Global Journal of Foreign Language Teaching, 8(1), 29-42.

Major, C. A. (2014). The effect of age on second language acquisition in older adults (Master's thesis, Brigham Young University, Provo, Utah, USA). Retrieved from https://scholarsarchive.byu.edu/cgi/viewcontent.cgi?article $=4972 \&$ context $=$ etd

Malik, A., Nyoto, A., Arismunandar, Suseto, B., Anjaya, C. Chodijah, I., ... Toharudin, T. (2018). Pedoman akreditasi Sekolah/Madrasah 2018 
[School/Madrasah accreditation guidelines 2018]. Retrieved from http://bansm.kemdikbud.go.id/unduh/get/23

Mardiani, R. (2011). The washback effect of English National Examination (ENE) on English teachers' classroom teaching and students' learning: A case study at three secondary schools in Bandung, East Java, Indonesia (Unpublished doctoral dissertation, Universitas Pendidikan Indonesia, Bandung, Indonesia).

McKay, P. (2006). Assessing young language learners. Cambridge University Press.

Meidasari, V. (2017). The assessment and evaluation in teaching English as a foreign language. Indonesian EFL Journal 1(2), 224-231.

Meisani, D. R. (2017). The effectiveness of English education at a public elementary school in Indonesia in enhancing English for young learners. Paper presented at the $10^{\text {th }}$ CONAPLIN and the $1^{\text {st }}$ ICOLLITE (pp. 80-85). SCITEPRESS.

Meisani, D. R. (2018). Read-to-Me' story books: Parent-child home English reading activities. Paper presented at the 15th Asia TEFL and 64th TEFLIN International Conference on English Language Teaching (pp. 522-536). Taylor \& Francis.

Mizumoto, A., Sasao, Y., \& Webb, S. A. (2017). Developing and evaluating a computerized adaptive testing version of the Word Part Levels Test. Language Testing, $00(0), 1-23$.

Moinzadeh, A. R., Talebinezhad, M. R., \& Behazin, A. (2008). Exposure density in relation to learning and retention to in EFL. International Journal of Humanities, 15(2), 71-97.

Montrul, S. \& Foote, R. (2014). Age of acquisition interactions in bilingual lexical access: A study of the weaker language of L2 learners and heritage speakers. International Journal of Bilingualism, 18(3), 274 -303.

Musthafa, B. (2010). Teaching English to Young Learners in Indonesia: Essential Requirements. Educationist, 4(2), 120-125. Retrieved from https://pdfs.semanticscholar.org/bc1a/5501436b8e67d956a31cf8303f520e eea7d4.pdf

Musthafa, B., \& Hamied, F. A. (2014). Conditions for English language learning in Indonesia: What Indonesian teachers of English have attempted to do to enhance students' English learning. In B. Spolsky \& K. 
Sung. (Eds.), Conditions for English language teaching and learning in Asia (pp. 63-76). Cambridge Scholars Publishing.

Nakata, Y. (2010). Improving the classroom language proficiency of nonnative teachers of English: What and how? RELC Journal, 41(1), 76-90.

Nikolov, M. (Ed.). (2016). Assessing young learners of English: Global and local perspectives. Retrieved from http://www.springer.com/series/5894

Othman, J. \& Kiely, R. (2016). Preservice teachers' beliefs and practices in teaching English to young learners. Indonesian Journal of Applied Linguistics, 6(1), 50-59.

Oxford University Press. (2013). Oxford young learners' placement test: Teacher's handbook. Retrieved from https://www.oxfordenglishtesting. com/uploadedFiles/6_New_Look_and_Feel/Content/YL_Handbook_Full. pdf

Pinter, A. (2011). Children learning second languages. Palgrave Macmillan.

Saidi, A., A. \& Al-Mahrooqi, R. (2012). The influence of gender on Omani college students' English language learning strategies, comprehension and motivation. International Journal of Applied Linguistics \& English Literature, 1(4) 230-244.

Salahshour, F., Sharifi, M., \& NedaSalahshour. (2013). The relationship between language learning strategy use, language proficiency level and learner gender. Procedia - Social and Behavioral Sciences, 70, 634 - 643.

Samiyan, L. V. (2015). A study on relationship between gender, learning strategies and achievement among Iranian EFL learners. Journal of Literature, Languages and Linguistics, 12, 83-86.

Schaik, B. (2009). Indonesia's education policy: Enabling innovation and growth. (Master's thesis, Delft University of Technology, Delft, Netherlands). Retrieved from https://repository.tudelft.nl/islandora/object/ uuid:661db69c-b21d-49f9-8a8b-7ac01ca8220c/datastream/OBJ/download

Scott, W. A. \& Ytreberg, L. H. (1990). Teaching English to children. Longman.

Sinanovic, J., \& Becirovic, S. (2016). The determinants of lifelong learning. European Researcher, 103(2), 107-118.

Singleton, D. (1999). Exploring the second language mental lexicon. Cambridge University Press. 
Solanki, S. M. \& Xu, D. (2018). Looking beyond academic performance: The influence of instructor gender on student motivation in STEM fields. American Educational Research Journal, 55(4), 801-835.

Spolsky, B. (1989). Conditions for second language learning. Oxford University Press.

Sukardjo, M. \& Komarudin, U. (2009). Landasan pendidikan: Konsep dan aplikasinya [Educational foundations: Concepts and applications]. Rajawali Pers.

Tsang, A. (2017). EFL/ESL teachers' general language proficiency and learners' engagement. RELC Journal, 48(1) 99-113.

Tseng, Y. (2014). Effects of early exposure to a second language on its proficiency at later age. Journal of Modern Education Review, 4(6), 418426.

Wang, Q. (2015). A study of the influence of gender differences on English learning of senior high school students. Higher Education of Social Science, 8(6), 66-69.

Westbrook, J., Durrani, N., Brown, R., Orr, D., Pryor, J., Boddy, J., \& Salvi, F. (2013). Pedagogy, curriculum, teaching practices and teacher education in developing countries. Final Report. Education Rigorous Literature Review. Department for International Development. Retrieved from https://eppi.ioe.ac.uk/cms/Portals/0/PDF\%20reviews\%20and\%20summari es/Pedagogy\%202013\%20Westbrook\%20report.pdf?ver=2014-04-24121331-867

Woolfolk, A. (2014). Educational psychology. Pearson.

Yang, X., Lin, Y., Gao, M., \& Jin, X. (2018). Effect of modulating activity of DLPFC and gender on search behavior: A tDCS Experiment. Frontiers in Human Neuroscience, 12(325). Retrieved from https://www.ncbi.nlm. nih.gov/pmc/articles/PMC6110849/

Zhogi, M., Kazemi, S. A., \& Kalani, A. (2013). The effect of gender on language learning. Journal of Novel Applied Sciences, 2(4), 1124-1128. 